\title{
Cultural Influences on Negotiations between the Chinese and the British in Higher Educational Settings in the UK
}

\author{
Olotuah Damilola Esther ${ }^{1 *}$ and Olotuah Abiodun Olukayode ${ }^{2}$ \\ ${ }^{1}$ Sheffield Hallam University, UK \\ ${ }^{2}$ Department of Architecture, Federal University of Technology, Nigeria
}

Submission: July 08, 2018; Published: August 13, 2018

*Corresponding author: Olotuah Damilola Esther, Sheffield Business School, Sheffield Hallam University, Sheffield, UK, Email:dami.olotuah@gmail.com

Keywords: Negotiation; Cultures; International negotiations culture; Cultural differences; Cultural settings; Counterparts

\section{Introduction}

This research was carried out to investigate the cultural differences between the Chinese and British people and how these affect negotiations between them in higher education settings at Sheffield Hallam University UK. A lot is documented in the literature from researches on culture and negotiation in the context of the Chinese and Westerners (Europeans and North Americans). This research is a contribution to knowledge on the influence of culture on negotiations between the Chinese people and the British in higher educational settings in particular and how they manage their cultural differences and the styles adopted during negotiations.

The term 'negotiation' according to Thompson [1] refers to a joint decision-making process whereby two or more individuals with diverse interests agree on how to allocate resources. Mahbubani [2] asserts that negotiations have played a key role in international business relations. People negotiate on a daily basis considering the fact that the world is becoming a global village. Negotiations have become a remarkable area of study for researchers and many studies have been carried out. Cultures like Chinese, Japanese, and North American have been examined [3].

A negotiation in international settings is successful when managers have the ability to adequately communicate their messages in different cultural settings [4]. They must also understand the cultural differences that exist between them and their counterparts. Yet, due to a lack of understanding of the cultures involved in negotiations and the inability to effectively communicate to individuals from different cultural backgrounds, international negotiators still fail. Imitating, concluding, even maintaining negotiations is a bit challenging
[5]. Hence international negotiators must be culturally intelligent in understanding the culture of their counterparts so as to understand their business negotiating styles and thus communicate effectively [6]. Although, negotiators must understand the style of the other party during a negotiation, Osman-gani et al. [3] argue that negotiators must also understand their own style of negotiating so that they will know how best to deal with negotiators from other cultures.

The negotiators from different cultures have different business negotiating styles which are influenced by the culture of the negotiating party, individual perceptions, communication, and lifestyles [6]. However, being unaware of the negotiating style of the other party can impede negotiations especially inter-cultural negotiations [7]. Negotiating with the Chinese is becoming dominant because the political and economic life of both the People's Republic of China and the Chinese diaspora communities is appealing to foreign direct investments [8]. China has experienced quick socio-economic development. It is the second largest economy with a population of over 1.3 billion people. China is an emerging country with rapid growth switching from centrally-planned to a marketbased economy [9]. The growth rate per capital GDP was about $7.3 \%$ as at 2014. Exportation of goods is about $22.61 \%$ of GDP while importation of goods is about $18.92 \%$ of GDP [10]. It is thus not surprising that foreign negotiators find themselves negotiating with the Chinese people [11]. Despite the rapid economic growth and social development in China, there exist some differences between the Westerners and Easterners in terms of culture which influence the way they negotiate during business deals [12]. 
In international negotiations culture plays a vital role. Researches have been made on the importance of culture on negotiations as well as the use of negotiation styles [13]. Understanding cultural differences will lessen misconceptions between people of different cultures [14]. One of the factors for a successful negotiation is culture. It has a significant influence on business negotiations especially on business matters [15]. According to Livermore [16], it is one thing to understand the cultural differences between Westerners and the Chinese people, it is however another thing to be able to develop a working relationship that will ensure that both parties attain their set goals and objectives.

The aim of this research was to examine how culture influences negotiations between the Chinese and the British in higher educational settings at Sheffield Hallam University, with the view to developing a framework for a broad understanding of how to negotiate successfully with one another and to ameliorate problems that can arise in the course of negotiations.

\section{Culture}

Culture is the totality of the way of life of a people, their material and non-material expressions, and their capability to adjust to their environment. Culture encapsulates the entire social, economic, anthropological, ecological, political, and spiritual make-up of a people. It is the patterned ways of thinking, feeling, and reacting acquired and transmitted mainly through symbols [17]. It is the personality of a social group which encompasses both the norms and values shared by the members of that group [18]. Culture is influenced by a large number of factors such as religion, education, nationality, social class, gender, family, ethnicity, language, legal, and political system [19-22].

According to Osman-gani et al. [3] in the area of management, diversity in culture has been given a lot of attention. This is because in a cross-cultural setting it involves people from various cultures coming together with different ways of how they view life. Usunier \& Lee [22] assert that culture is also influenced by religion, education, nationality, social class, gender, family, ethnicity, language, and legal and political systems. The way people perceive and react to them is significantly influenced by their culture [23]. Culture is an intrinsic factor that has to be taken into consideration in order to have a successful negotiation. Culture greatly influences how individuals think, communicate and behave [24]. Thus, it has a great influence on negotiations because parties involved in cross-cultural negotiations are from different cultures.

A cross-cultural negotiation is a multifaceted concept which has a significant influence on culture [7]. Individuals that have the same cultural background are likely to think similarly, act in some certain ways, and reason alike because of their cultural identity which might not be so for people from a different cultural background [22]. When dealing with people from different cultures it requires communications [25]. In a negotiation context, culture not only influences a negotiation strategy but also the communication style [26]. According to Gudykunst \& Nishida [27] the only framework developed to date, based on communication and applied to different facets of communication is the Hall's scheme. Cultures are distinguished on the basis of the communication that prevails in the culture [28].

One of the cultural factors that affect the outcome of a negotiation is individualism/collectivism [29]. It is a frequently used element in cross-cultural research [30]. In an individualistic culture people are mostly concerned about themselves and not others, and they make decisions individually. Attention is placed on individual goals over common goals [31]. According to Triandis [32] people from countries with individualistic cultures, e.g. England, are taught to be competitive, independent, self-confident, and original.

In collectivist cultures people see themselves as being in a relationship; they see themselves as being socially bonded together [33]. Goals, obligations, and responsibilities of the group are usually valued over the needs and goals of individuals. According to Steele \& Lynch [34] China is a collectivist culture. Collectivist cultures such as China value group harmony than personal interests [24]. The people prefer to work in teams during international business negotiations. They value relationships and see the need to maintain harmony within their group [23]. The decision that affects the group is on a consensual basis [31]. Since the Chinese value relationships and harmony during negotiations they try to maintain harmony and interpersonal relationships. Conversely, individualistic cultures focus on their own self interests [23]. These differences affect negotiation practices.

In order to have an effective negotiation, negotiators have to understand the cultural differences between themselves and their counterparts because the negotiating styles between them differ [35]. For instance the Chinese people prefer to build a long-term relationship with their counterparts whereas the British go straight to business rather than building a relationship with their counterparts. Social status is another issue; the British call one another by their first names whereas in China it is different. This is because the issue of superiority remains strong is China [36]. Thus, one of the vital aspects that needs to be examined for a successful negotiation is awareness of cultural differences.

\section{Negotiations}

A negotiation is a joint-making decision process whereby two or more individuals with diverse interests agree to allocate resources [1]. In international settings, negotiators must understand the cultural differences between them and 
their counterparts because a negotiation is successful when negotiators can communicate their messages adequately in different cultural settings [4]. Yet international negotiators still fail because of the inability to effectively communicate their messages to individuals from different cultural backgrounds. Business negotiators from different cultures have different business negotiating styles thus these negotiating styles are influenced by the negotiating party's culture: individual perception, communication, and lifestyles [6]. However, being unaware of the negotiating style of the other party can impede negotiations especially inter-cultural negotiations [7].

Negotiating with the Chinese is becoming more dominant because the political and economic life of both the People's Republic of China and the Chinese Diaspora communities is appealing to foreign direct investment [8]. China has experienced quick socio-economic development. It is the second largest economy with a population of over 1.3billion people. China is an emerging country with rapid growth switching from centrally-planned to a market-based economy [9]. The British and the Chinese people have different approaches during negotiations and the differences stem from their cultural backgrounds. An understanding of the differences can prevent misconceptions between individuals and thus create mutually favourable relationships [14]. Culture plays an important role in international business negotiations and this influence can either make or mar a transaction. It can also affect the kinds of transactions made and the way they are negotiated.

\section{Chinese culture in negotiation}

It is known that Chinese business negotiators have a negotiation emphasis that is different from that of the Westerners. However, their values are subject to change depending on the negotiation circumstances [37]. The Chinese people tend to be of lower acculturation in negotiations, that is they know less about each other's culture. In other words they have to use their own mother tongue and negotiation styles during a negotiation because it difficult to completely adapt to the Western culture and the Western style of negotiating [38].

According to Triandis [39] there are two basic points of view to the study of culture; the Emic (culture-specific) and the Etic (culture-general). Chinese negotiation style comes from their culture and tradition. The Chinese negotiation style can be complex but it is not unfathomable and it depends on a person's in-depth understanding about the Chinese culture [40]. The Chinese culture can be classified into Confucianism which deals with human relationships, the Chinese stratagem, and guoqing which is the modern day "social political system and conditions of the People's Republic of China" [40]. The Chinese negotiators are subject to change depending on the negotiation circumstances. They can either blend to adapt to be Confucian or strategist depending on the rule of the game [41].

\section{British culture in negotiation}

In Britain the process of negotiation is seen as a business deal and is largely divorced from other aspects of society and from the personal and social lives of the negotiators [42]. The negotiations are largely technical processes with technical outcomes. The whole process is an economic exchange process. According to Katz [43] the issue of building a relationship and trust is important as in other countries like China, but it is not a must in business negotiations to the British. The British people see a negotiation as a joint problem-solving matter; they are very pragmatic and they expect to know people better as they engage in doing business. A person is respected in the business culture of Britain based on his rank, education, or status. The high points of the British culture in negotiations are communication, monochromic style, bargaining, and contracts and agreements. Verbal agreements are usually considered binding and they are normally kept. They often times write out the terms and conditions for their major agreements which are always signed [43].

\section{Methodology}

The research is inductive so a qualitative approach was adopted. This is because the inductive approach gives more chances to having more explanations to research questions [44]. Mack, et al. [45] assert that it is valid for obtaining specific information about opinions, behaviours, and the social contexts of people. Harwood [46] asserts that in order to gain a deeper understanding on negotiations, qualitative approach is satisfactory. Furthermore, gathering data using the semistructured, in-depth interviews are associated with qualitative method which gives room to answering the questions of what, why, and how rather than how many, and how much [47].

The aim of this research was to examine how culture influences negotiations between the Chinese and the British in higher educational settings at Sheffield Hallam University, with the view to developing a framework for a broad understanding of how to negotiate successfully with one another and to ameliorate problems that can arise in the course of negotiations.

\section{Research objectives}

A. To examine the extent to which cultural differences influence Chinese and British in negotiation

B. To investigate how British and Chinese people manage cultural differences during Negotiation

C. To investigate the strategy used during negotiation and to find out if they are influenced by culture.

Semi-structured interviews were conducted at the Sheffield Business School in Sheffield Hallam University, and SHU Beijing office in China. The interviews were conducted face-to-face at the Sheffield Business School, while the Chinese respondent 
was interviewed via Skype due to her international location in China. The interviews were recorded and transcribed verbatim in order to generate relevant themes. A thematic framework guided the analysis of the data, and it provided an insight into the planned study.

\section{Findings and Discussions}

The study explored the impact of culture and negotiations between the British and the Chinese people. It was examined from the participants' points of view. It was observed by all participants that cultural differences exist between the British and the Chinese people. However according to one of the participants sometimes the issue may not just be about understanding the other party. In her view sometimes it is possible that two British negotiators may have difficulties in understanding each other. This is in accordance with the idea of Osman-gani et al. [3] that although understanding the other party's culture and negotiating style are important, however, it is also very important to understand one's own culture and negotiating styles as well so as to be able to deal with negotiators from other cultures.

Putting one's self in the other party's shoes in order to achieve a successful negotiation was a point raised by the Chinese participant. She was of the view that a negotiation can only be successful if individuals put themselves in the other party's shoe in order to see things from their own perspectives. This is supported by Fisher, et al. [48] that considering the other party is one of the important steps for a successful negotiation which is often referred to as the traditional perspective taken in negotiations [49].

All the participants agreed that cultural differences shape the British and the Chinese negotiations. According to Hofstede [24] culture influences how individuals think, communicate, and behave. Thus culture has an influence on a negotiation (particularly cross-cultural negotiation) because individuals are from different cultures. Furthermore, even though understanding cultural differences that exist between parties of different cultures is necessary, it is however important to know what strategy is best to apply when dealing with people from different cultures. The participants gave their different views as regard this. In the opinion of one of the participants, because they do not want to offend anyone during negotiations they rather keep quiet. Sometimes because they want a successful deal with the other party they tend to compromise rather than saying no directly. This could be linked to Rubin, et al. [50] that compromising is the moderate concern for one's own interest and a moderate concern for the interest of the other party.

In the view of one of the British participants the British focus more on short term relationships. However, this is not so in all cases. She said the negotiation basis sometimes depends on whether it is going to be long term or short-term relationship.
The British will likely go for a long-term relationship when the deal is not a transactional deal e.g. an educational stand point. But when the deal is a transactional deal then the British do not care about building a long-term relationship with the other party. Buttery \& Leung [42], support this by asserting that relationship building is not a must in business negotiations with the British. Meanwhile from the participant's point of view a British negotiator will engage in a long-term relationship when it is not a transactional (business) negotiation. All the participants agreed that cultural differences shape the British and the Chinese negotiations. According to Hofstede [24], culture influences how individuals think, communicate and behave. Thus culture has an influence on a negotiation (particularly cross-cultural negotiation) because individuals are from different cultures. In addition, culture also influences communication styles. This can also be viewed from the perspective of Adair [51], who asserts that Westerners focus on direct communication (very precise, direct and verbal) while Easterners focus on indirect communication (nonverbal communication).

One of the participants who delt with the Chinese and the British students mentioned that because in the West people are very direct in talking, whereas in the East people are very symbolic she has tailored her language in a way that the Chinese students will understand her clearly and vice-versa. This is because a slight change of tone can mean a different thing entirely to the Chinese so she always tries to make sure that she understands what they say and also what she says to them. In other words patience is the key to making sure that one is clearly understood by the other person involved in the negotiation because of cultural differences. This claim is supported by Hofstede \& Minkov [52] that a negotiation becomes effective when the parties involved in a negotiation understand their cultural differences.

This can also be linked to cultural intelligence. A culturally intelligent negotiator is able to effectively communicate in a cross-cultural environment. When an individual is culturally intelligent it lessens the challenges of cultural differences because they can easily adapt to various situations they find themselves in [31]. One of the participants mentioned that whenever they need to negotiate and recommend someone to travel to China they always recommend a person who has international experience, and understands cultural differences, and will behave appropriately. This supports the fact that cultural intelligence can help reduce the challenges of differences due to cross-cultural settings, and also negotiators who have cultural intelligence will be able to effectively adapt and adjust in a different cultural setting [53]. This however applies to all negotiators whether in the private sector or in the public sector.

In order to be successful ininternational operations, cultural intelligence is an important factor [54]. The differences within 
cultures are recognised by a culturally intelligent individual and to be successful, it is important that organisations adapt to these cultural differences. In other words to be successful in an international operation, a negotiator has to be culturally intelligent whether in the higher educational sector (HE) or private sector.

\section{Conclusion}

The research examined the impact of culture on negotiations between the British and the Chinese people. It was examined from the participants' points of view. Due to the economic growth and social development in China, it is not surprising that other countries find themselves negotiating with the Chinese. A lack of understanding of the cultural differences between the Westerners and the Easterners especially in terms of the way business deals are negotiated can hinder a successful negotiation. Being a qualitative and interview-based study, the research focused on the participants' perspectives, and the interviews were transcribed verbatim. It is observed that the British and the Chinese are two different cultures and understanding the cultural differences between them lessens culture shock that may arise during negotiations. In a nut shell, preparation is the key to a successful negotiation. This will reduce culture shock that may arise as a result of unawareness about a different culture. Brett [55] asserts that a negotiator who is culturally aware will be successful in business dealings abroad. In other words, cultural awareness is the first key to a successful cross-cultural negotiation.

\section{References}

1. Thompson L (2000) The mind and heart of the Negotiator, (2 ${ }^{\text {nd }}$ edn). Prentice-Hall, Upper Saddle River, NJ, USA.

2. Mahbubani $\mathrm{K}$ (2012) The global village has arrived. Finance and development 49(3).

3. Osman-gani AM, Tan JZ, Yahia H, Volkema R (2002) Influence on culture on Negotiation styles of Asian managers: An empirical study of major cultural/ethic groups in Singapore. Thunderbird International business review 44(6): 819-839.

4. Schoop M, Kohne F, Ostertag K (2010) Communication quality in business negotiation. Group Decision and Negotiation 9(2): 193-209.

5. Crump L (2011) Negotiation process and Negotiation context. International negotiation 16(2): 197-227.

6. Chang L (2003) An examination of cross cultural negotiation: Using Hofstede framework. Journal of American Academy of Business Cambridge 2(2): 567-570.

7. Tung RL (1994) Strategic management thought in East Asia. Organizational Dynamics 22(4): 55-65.

8. Redding G and Witt M (2008) The future of Chinese capitalism. Oxford University Press, Oxford, UK.

9. World Bank Group (2002) China data profile.

10. Global EDGE (2015) China.

11. Hitt M, Franklin V, Zhu H (2006) Culture, institutions and international strategy. Journal of International Management 12: 222-234.
12. Ma Z (2010) The sins of business negotiation: Explore the crosscultural differences in business ethics between Canada and China. Journal of Business ethics 91(1): 123-135.

13. Tu Y (2014) Cross cultural equivalence and Latent mean differences of the negotiation style

profile in Taiwan and US managers. International Journal of Intercultural relations 43(9): 156

14. Mole J (1998) Mind Your Manners: Managing Business Cultures in Europe, (Ed.) (London: Nicholas Brealey), UK.

15. Danciu V (2010) The impact of the culture on the international negotiations: An Analysis based

on contextual comparisons. Theoretical and Applied Economics 8(549): $87-102$.

16. Livermore D (2010) Leading with cultural intelligence, New York, USA.

17. Roger V and Fleck D (2012) Understanding Propensity to Initiate Negotiations: an examination of the effects of culture and personality. International Journal of Conflict Management 23 (3): 266-289.

18. Brett JM (2000) Culture and Negotiation. International Journal of Psychology 35 (2): 97 -104.

19. Olotuah AO (1997) The House: Accessibility and Development - A Critical Evaluation of the Nigerian Situation. In: Bayo Amole (Ed.) The House in Nigeria, Proceedings of the National Symposium, Obafemi Awolowo University Ile-Ife, Nigeria, pp. 312-317.

20. Olotuah AO (2006): At the Cross-Roads of Architectural Education in Nigeria CEBE Transactions. Online Journal of Centre for Education in the Built Environment (CEBE), Cardiff University, UK 3(2): 80-88.

21. Olotuah AO \& Olotuah DE (2016) Space and Cultural Development in Hausa Traditional Housing, International Journal of Engineering, Sciences, and Research Technology 5 (9): 654-659.

22. Usunier J, Lee JA (2009) Marketing across culture ( $2^{\text {nd }}$ edn), Pearson Education Limited, Essex, England.

23. Ma Z, Jaeger A (2010) A comparative study of the influence of assertiveness on negotiation on negotiation on negotiation outcomes in Canada and China, Cross Cultural Management. An International Journal 17(4): 333-346.

24. Hofstede G (2001) Culture's consequences: International differences in work related values, Beverly Hills. Sage Publications, CA, USA.

25. Perkins S, Shortland S (2006) Strategic international human resource management, Choices and consequences in multi-national people management ( $2^{\text {nd }}$ edn), kogan page limited, London and Philadelphia.

26. Adair W, Okumura T and Brett J (2001) Negotiation behaviors when culture collide: The US and Japan. Journal of Applied Psychology 86(3): 371-385.

27. Gudykunst WB and Nishida T (1986) Attributional confidence in low and high context cultures. Human Communication Research 12(4): 525-549.

28. Hall E (1976) Beyond culture. Anchor press, New York, USA.

29. Kim T, Shapiro D (2008) Retaliation against supervisory mistreatment: Negative emotion, Group membership and Cross-Cultural Differences. International Journal of Conflict Management 19(4): 339-358.

30. Triandis HC (1988) Collectivismvs.individualism:A reconceptualization of a basic concept in cross-cultural social psychology, Cross-cultural studies of personality, attitudes and cognition, London: MacMillan, UK: 60-95.

31. Thomas D, Inkson K (2009) Cultural intelligence: Living and working globally. Berrett Koehler Publishers Inc, San Francisco, CA, USA. 
32. Triandis H (1995) Individualism and Collectivism, Boulder, CO Westview Press.

33. Markus HR, Kitayama S (1991) Culture and the self: Implications for cognition, emotion and Motivation. Psychological Review 98(2): 224253.

34. Steele L, Lynch S (2013) The pursuit of happiness in China: Individualism, Collectivism and Subjective well-being during China's Economic and Social Transformation. Social Indicators Research 114(2): 441-451.

35. Horwitz F, Hemmant R, Rademeyer C (2008) Chinese business negotiation: South Africa firm experiences and perspectives. SA Journal of Business Management 39(1): 1-13.

36. Graham J, Lam M (2003) The Chinese Negotiation. Harvard Business Review 81(10): 82-91.

37. Warden C, Chen J (2009) Chinese Negotiators Subjective Variations in Intercultural Negotiations. Journal of Business Ethics 88(3): 529-537.

38. Jiang Y (2013) Business negotiation culture in China A Game Theoretic Approach, International Business Research 6(3): 109-116.

39. Triandis HC (1994) Culture and social behavior, New York: McGrawHill, USA: $169-173$.

40. Fang T (2006) Negotiation: the Chinese style, Journal of Business \& Industrial Marketing 21(1): 50-60.

41. Chu CN (1992) Thick Face, Black Heart: The Path to Thriving, Winning and Succeeding. AMC Publishing, Beaverton, Oregon, USA.

42. Buttery EA, Leung TKP (1997) The difference between Chinese and Western negotiations European. Journal of Marketing 32(3/4): 374 -389 .

43. Katz L (2006) Negotiating International Business - The Negotiator's Reference Guide to 50 Countries Around the World, ( $2^{\text {nd }}$ edn), Book surge, California, USA.
44. Saunders M, Lewis Philip, Thornhill A (2003) Research methods for business students ( $3^{\text {rd }}$ edn), Harlow, Pearson Education.

45. Mack N, Woodsong C, MacQueen K, Guest G and Namey E (2005) Qualitative Research Methods: A Data Collector's Field Guide, USAID, Family Health International, USA.

46. Harwood T (2002) Business negotiations in the context of strategic relationship building, Marketing Intelligence and planning 20(6): 336348.

47. Ritchie J, Lewis J, Mcnaughton C, Ormston R (2013) A Guide for Social Science Students and Researchers, Los Angeles, Sage Publications, USA.

48. Fisher R, Ury W, Patton B (1991) Getting to yes, Penguin Books, New York, USA.

49. Sujin L Wendi A, Seong-Jee S (2013) Cultural perspective taking in Cross-Cultural Negotiation. Group Decision and Negotiation 22 (3): 389-405.

50. Rubin J, Pruitt D, Kim S (1994) Social conflict: Escalation, stalemate and settlement. New York: McGraw-Hill, USA.

51. Adair W (2003) Integrative sequences and negotiation outcome in same and mixed culture negotiations. International Journal of Conflict Management 14(3/4): 273-296.

52. Hofstede G and Minkov M (2010) Culture and Organisation software of the mind ( $3^{\text {rd }}$ edn), McGraw-Hill, New York, USA.

53. Earley C, Ang S (2003) Cultural Intelligence: Individual, interactions across cultures. Standard University Press, Palo Alto, CA, USA.

54. Creque C, Gooden D (2011) Cultural Intelligence and Global Business Competencies: A Framework for Organizational Effectiveness in The Global Marketplace. International Journal of Management and Information Systems 15(4):141-146.

55. Brett J (2001) Negotiating globally: How to negotiate deals, resolve dispute and make decisions across cultural boundaries. San-Francisco, USA.
Your next submission with Juniper Publishers will reach you the below assets

- Quality Editorial service

- Swift Peer Review

- Reprints availability

- E-prints Service

- Manuscript Podcast for convenient understanding

- Global attainment for your research

- Manuscript accessibility in different formats

( Pdf, E-pub, Full Text, Audio)

- Unceasing customer service

Track the below URL for one-step submission

https://juniperpublishers.com/online-submission.php 